\title{
The status of infant health in India
}

\author{
Susmita Bharati, Manoranjan Pal, Premananda Bharati
}

Indian Statistical Institute, Kolkata, India; Manoranjan.pal@gmail.com

Received 26 June 2013; revised 26 July 2013; accepted 10 August 2013

Copyright (C) 2013 Susmita Bharati et al. This is an open access article distributed under the Creative Commons Attribution License, which permits unrestricted use, distribution, and reproduction in any medium, provided the original work is properly cited.

\section{ABSTRACT}

This paper investigates the present status of infant health in India through percentages of infants who are undernourished, not immunized or diseased and finds its relationship with socio-demographic variables. The relevant data have been obtained from the Third National Family Health Survey which was carried out in 2005-2006 in India. The sample consists of 7562 infants (i.e., children of less than 1 year). For socio-demographic data, places of residence, sex of infants, ethnic composition, religion and wealth index were considered. Considering the different types of under-nutrition, it has been found from our data that the percentages of undernourished infants range from 22 to 28 only. There are considerable variations in the different types of immunization status ranging from $17.9 \%$ opting for measles vaccination to $73.2 \%$ taking BCG vaccination. Prevalence of morbidity also varies from 15 to 22 percent depending on the three types of morbidity considered in this paper. Among the socio-economic variables, mother's education and wealth index have been found to have profound effect on the nutritional status and also on morbidity of infants but there is no impact found on the status immunization. Thus it gives clear cut indications for the government and NGOs to take actions to ameliorate poverty and to improve the level of education, especially of female population in India.

Keywords: Height-for-Age; Weight-for-Height; Weight for Age; Morbidity; Immunization Status; Infants; India

\section{INTRODUCTION}

India is home to the largest number of undernourished children. Globally, the status of under-nutrition is improving over time; still, India contributes to the largest number of underweight children in the world. Physical growth and malnutrition situation are the comprehensive reflections of child nutritional status. The main indicator of malnutrition among children is the protein-energy malnutrition and this is usually reflected by the anthropometric measures of relative values of height, weight and age of children. Underweight, wasting and stunting of children can be measured through weight-for-age, weight-for-height and height-for-age respectively. Under weight and wasting are the effects of acute deficiency and stunting is the result of chronic deficiency. Growth during infancy depends on children's duration of breastfeeding and their birth weight. Data from last five decades prove that exclusive breast-feeding first six months is most effective for normal growth of babies. However, exclusive breastfeeding beyond six months should not be practiced as it causes poor growth among infants. Infants are likely to suffer from various types of morbidity if they are not brought up in a hygienic condition and semisolid food is not introduced from six months onwards. Malnutrition has also been seen to cause morbidity among children in developing countries [1-6].

In India, Universal Immunization Programme (UIP) for six vaccine-preventable diseases (Tuberculosis, Diaptheria, Whooping Cough, Tetanus, Polio and Measles) are launched in 1985 with the objective of reducing morbidity, mortality and disabilities among the children. This programme envisaged immunization to all eligible children by 1990. Immunization was chosen as the most effective way to tackle disease because measles in a healthy child is not very serious but mortality due to measles is 400 times greater in an undernourished population. Similarly, if an adequate drinking water is made available, poliomyelitis will cease to be a problem and it inhibits morbidity.

From many studies, it becomes clear that a number of factors affect the child nutrition either directly or indirectly. These factors are food availability, dietary intake, breast-feeding, prevalence of infectious and parasitic disease, water supply and sanitation, socio-economic status. Several studies also show that repeated episodes of infectious diseases adversely affect children nutri- 
tional status [7,8]. Thus, the objectives of the present study are 1) to assess the status of infant health through three dimensions of health namely nutritional, morbidity and immunization and 2) to find the most effective socio-economic factors towards prevention of malnutrition, morbidity and lack of immunization of infants.

\section{METHODOLOGY}

The data on growth and nutritional status of children was accessed from the third round National Family Health Survey (NFHS-3) of 2005-2006. The survey was coordinated by International Institute for Population Sciences (IIPS) [9] in collaboration with the Ministry of Health and Family Welfare. Children of age $0-11$ months (i.e., less than one year as it is taken last birth day) are taken for our study. The sample sizes for India is 8225 . For assessing the nutritional status, this survey collected data on weight and height of the infants as well as computed " $Z$ " scores through weight for age, height for age and weight for height indices.

Z-score value "-2" was used as a cut-off point for prevalence estimation [10]. Z-score is defined as the deviation of the value observed for an individual from the median of the reference population, divided by the standard deviation (SD) of the reference population i.e.

$$
\begin{aligned}
& \text { Z-score } \\
& =\frac{(\text { Observed value })-(\text { Median of the ref. population })}{(\text { SD of the reference population })}
\end{aligned}
$$

The classifications of Z-score (followed by NCHS/ WHO) are "below normal" (<-2), "normal" $(2$ to +2$)$ and "above average" $(>+2)$.

The infant is considered as fully vaccinated if the infant has taken one dose for BCG, three doses for DPT and Polio and single dose of measles before one year. Data on immunization status are verified from vaccination cards and in case, where a vaccination card was not available or a vaccination was not recorded on the card, the mother's recall of vaccination was accepted.

For assessing three morbidity statuses of infants like diarrhea, fever and cough, mother of infant was asked if the children was suffering from the disease during the two weeks preceding the survey by recall method. It should be noted that the morbidity data collected on the basis of mother's perceptions of illness without validation by medical personnel.

For socio-demographic data, places of residence are taken as "rural" and "urban". Sex of infants has also been considered. Ethnicity wise four groups have been taken namely Scheduled Castes, Scheduled Tribes, Other Backward Classes and "Others". Religions are grouped into four categories as Hindus, Muslims, Christians and "Others". Mother's educational status have four catego- ries namely Illiterate (those who can neither read nor write), Primary (literate up to Class IV standard), Secondary (Class $\mathrm{V}$ to Class $\mathrm{X}$ standard) and Higher (i.e. Higher Secondary, Graduate or Post Graduate, etc.). Wealth index is a measure of the economic status of the household [11]. Though it is an indicator of the level of the wealth in the household, it is consistent with expenditure and income measure. It is based on 33 household assets and housing characteristics like household electrification, type of windows, sources of drinking water, types of toilet facility, flooring, roofing, cooking fuel and house ownership, material of exterior walls, number of household members per sleeping room, ownership of a bank or post-office account, ownership of a mattress, a pressure cooker, a chair, a cot/bed, a table, an electric fan, a radio/transistor, a black \& white television, a colour television, a sewing machine, a mobile telephone, and any other telephone, a computer, a refrigerator, a watch or clock, a bicycle, a motorcycle or scooter, an animaldrawn cart, a car, a water pump, a thresher, and a tractor. Here each household was assigned a score for each asset and the scores were summed for each household and divided into five quintile groups starting from lower strata to higher strata like poorest, poorer, medium, richer and richest. These categories were however supplied along with the data.

To see the relative and effective intervention, the risk of Z-score value for under-nutrition, immunization status and morbidity were regressed on socio-economic variables using categorical logistic regression analysis. Dependent variables are taken as binary. Children whose Z-scores are below -2 are coded as "1" and those with Z-scores -2 or higher are coded as " 0 ". For immunization status, not-immunized has taken as "1" and immunized is coded as " 0 ". For morbidity status, morbidity was considered as " 1 " and others are coded as " 0 ". An estimated odd ratio of " 1 " indicates that the nature of dependent variable is not different from the reference category. If the estimated odd ratio is $>1$, the probability of becoming affected is more in this category compared to the reference category and if it is $<1$, then it is just opposite to that of " $>1$ " case.

\section{RESULTS}

Table 1 indicates that in India, according to third phase of national family health survey data, $27.8 \%$ infants are underweight, $22.5 \%$ are stunted and $26.7 \%$ are wasted. By gender differences, underweight boys are $28.0 \%$ while girls are $27.6 \%$. $23.5 \%$ boys and $21.5 \%$ girls are stunted while $26.5 \%$ boys and $26.9 \%$ girls are wasted. Percentages of underweight and stunted infants have an increasing trend over ages in months, whereas percentage of wasted children has a decreasing trend.

Table 2 presents the non-immunization status of in- 
Table 1. Percentages of under-weight, stunted and wasted infants by gender and age in months in India, 2005-2006.

\begin{tabular}{|c|c|c|c|c|c|c|c|c|c|c|c|c|}
\hline \multirow{3}{*}{ Age in months } & \multicolumn{12}{|c|}{ Nutritional status } \\
\hline & \multicolumn{4}{|c|}{ Total } & \multicolumn{4}{|c|}{ Boys } & \multicolumn{4}{|c|}{ Girls } \\
\hline & $\mathrm{N}$ & Under-weight & Stunted & Wasted & $\mathrm{N}$ & Under-weight & Stunted & Wasted & $\mathrm{N}$ & Under-weight & Stunted & Wasted \\
\hline 00 & 184 & 16.8 & 17.9 & 27.2 & 104 & 11.5 & 16.3 & 27.9 & 80 & 23.8 & 20.0 & 26.3 \\
\hline 01 & 490 & 24.7 & 20.4 & 32.0 & 232 & 26.7 & 22.8 & 29.3 & 258 & 22.9 & 18.2 & 34.5 \\
\hline 02 & 628 & 26.1 & 19.6 & 28.5 & 307 & 25.4 & 20.2 & 29.6 & 321 & 26.8 & 19.0 & 27.4 \\
\hline 03 & 627 & 26.5 & 18.5 & 30.6 & 321 & 27.1 & 18.7 & 32.7 & 306 & 25.8 & 18.3 & 28.4 \\
\hline 04 & 691 & 24.9 & 17.2 & 25.8 & 330 & 22.1 & 17.0 & 23.3 & 361 & 27.4 & 17.5 & 28.0 \\
\hline 05 & 726 & 28.0 & 19.4 & 26.2 & 349 & 29.8 & 22.3 & 26.1 & 377 & 26.3 & 16.7 & 26.3 \\
\hline 06 & 710 & 27.5 & 21.8 & 25.4 & 365 & 28.2 & 22.2 & 24.9 & 345 & 26.7 & 21.4 & 25.8 \\
\hline 07 & 744 & 28.6 & 22.2 & 25.7 & 364 & 29.1 & 23.1 & 26.1 & 380 & 28.2 & 21.3 & 25.3 \\
\hline 08 & 760 & 28.3 & 24.2 & 25.7 & 414 & 25.1 & 22.5 & 24.6 & 346 & 32.1 & 26.3 & 26.9 \\
\hline 09 & 703 & 30.3 & 25.3 & 27.2 & 354 & 32.2 & 26.8 & 28.5 & 349 & 28.4 & 23.8 & 25.8 \\
\hline 10 & 690 & 30.4 & 28.1 & 25.8 & 347 & 33.4 & 30.8 & 25.6 & 343 & 27.4 & 25.4 & 25.9 \\
\hline 11 & 609 & 32.7 & 32.0 & 22.2 & 297 & 34.0 & 35.4 & 20.9 & 312 & 31.4 & 28.8 & 23.4 \\
\hline Total & 7562 & 27.8 & 22.5 & 26.7 & 3784 & 28.0 & 23.5 & 26.5 & 3778 & 27.6 & 21.5 & 26.9 \\
\hline
\end{tabular}

Source: NFHS-3, India.

Table 2. Percentages of non-immunized infants by gender and age in months in India, 2005-2006.

\begin{tabular}{|c|c|c|c|c|c|c|c|c|c|c|c|c|c|c|c|}
\hline \multirow{3}{*}{ Age in months } & \multicolumn{15}{|c|}{ Non-immunized status } \\
\hline & \multicolumn{5}{|c|}{ Total } & \multicolumn{5}{|c|}{ Boys } & \multicolumn{5}{|c|}{ Girls } \\
\hline & $\mathrm{N}$ & $\mathrm{BCG}$ & DPT3 & Polio3 & Measles & $\mathrm{N}$ & BCG & DPT3 & Polio3 & Measles & $\mathrm{N}$ & BCG & DPT3 & Polio3 & Measles \\
\hline 00 & 184 & 79.3 & 100.0 & 100.0 & 100.0 & 104 & 78.8 & 100.0 & 100.0 & 100.0 & 80 & 81.3 & 100.0 & 100.0 & 100.0 \\
\hline 01 & 490 & 64.5 & 99.8 & 99.2 & 99.1 & 232 & 67.2 & 100.0 & 99.6 & 99.4 & 258 & 62.0 & 99.6 & 98.8 & 99.6 \\
\hline 02 & 628 & 38.7 & 99.0 & 98.4 & 98.7 & 307 & 34.9 & 98.7 & 98.0 & 98.7 & 321 & 42.4 & 99.4 & 98.8 & 98.7 \\
\hline 03 & 627 & 29.7 & 95.8 & 93.0 & 98.4 & 321 & 25.3 & 95.3 & 92.2 & 98.2 & 306 & 34.3 & 96.4 & 93.8 & 98.0 \\
\hline 04 & 691 & 28.2 & 80.4 & 75.1 & 97.0 & 330 & 23.6 & 76.1 & 73.0 & 97.7 & 361 & 32.4 & 84.4 & 77.0 & 98.3 \\
\hline 05 & 726 & 22.0 & 60.6 & 51.4 & 96.8 & 349 & 20.6 & 61.3 & 52.1 & 96.6 & 377 & 23.3 & 59.9 & 50.7 & 96.3 \\
\hline 06 & 710 & 21.1 & 54.6 & 47.0 & 95.3 & 365 & 21.4 & 53.0 & 47.7 & 95.6 & 345 & 20.9 & 56.2 & 46.4 & 95.9 \\
\hline 07 & 744 & 21.2 & 48.7 & 37.9 & 91.8 & 364 & 20.1 & 47.8 & 37.6 & 92.5 & 380 & 22.4 & 49.5 & 38.2 & 93.2 \\
\hline 08 & 760 & 20.2 & 44.6 & 32.4 & 86.9 & 414 & 18.8 & 40.8 & 30.5 & 88.4 & 346 & 21.7 & 49.1 & 34.7 & 90.2 \\
\hline 09 & 703 & 18.9 & 42.7 & 33.3 & 74.0 & 354 & 18.1 & 40.1 & 31.9 & 74.4 & 349 & 19.8 & 45.3 & 34.7 & 74.8 \\
\hline 10 & 690 & 18.0 & 38.5 & 30.4 & 54.3 & 347 & 17.3 & 39.3 & 28.8 & 55.6 & 343 & 18.7 & 37.6 & 32.1 & 56.9 \\
\hline 11 & 609 & 17.6 & 35.1 & 23.8 & 45.1 & 297 & 16.5 & 33.0 & 22.9 & 44.5 & 312 & 18.6 & 37.2 & 24.7 & 43.9 \\
\hline Total & 7562 & 26.8 & 60.9 & 53.3 & 82.1 & 3784 & 26.6 & 60.4 & 52.5 & 81.7 & 3778 & 27.1 & 61.4 & 54.2 & 82.4 \\
\hline
\end{tabular}

Source: NFHS-3, India.

fants of India by gender over ages. It is seen that among all infants, BCG was not taken by only $26.8 \%$ infants in India while most of infants have not taken measles (82.1\%), DPT triple doses $(60.9 \%)$ and Polio-triple doses $(53.3 \%)$. When seen separately for boys and girls the picture is more or less same. As expected, in this case, the percentages of non-immunized infants decrease as age increases.

Table 3 describes the morbidity status of all infants as well as by each gender. It is seen that among Indian infants, $15.5 \%$ suffer from diarrhea, $17.3 \%$ from fever and
$22.1 \%$ from cough. These percentages are 16.4, 18.9 and 23.4 respectively for boys and 14.6, 15.6 and 20.7 respectively for girls. The maximum occurrence of diarrhea is at the age of six month and afterwards it goes down. It may be due to introduction of rice or other semisolid food at this age. Occurrences of fever and cough are also high after six months of age. From six or seven months onwards, the infants are allowed to go out from home and face climatic changes. The situation is similar when taken separately for boys and girls.

Table 4 describes the zone- and state-wise distribu- 
Table 3. Morbidity statuses of infants by gender and age in months in India, 2005-2006.

\begin{tabular}{|c|c|c|c|c|c|c|c|c|c|c|c|c|}
\hline \multirow{4}{*}{$\begin{array}{l}\text { Age in } \\
\text { months }\end{array}$} & \multicolumn{12}{|c|}{ Morbidity } \\
\hline & \multicolumn{4}{|c|}{ Total } & \multicolumn{4}{|c|}{ Boys } & \multicolumn{4}{|c|}{ Girls } \\
\hline & $\mathrm{N}$ & $\begin{array}{l}\text { Diarrhea } \\
\text { (recently) }\end{array}$ & $\begin{array}{c}\text { Fever } \\
\text { (Last } 2 \text { weeks) }\end{array}$ & $\begin{array}{c}\text { Cough } \\
\text { (Last } 2 \text { weeks) }\end{array}$ & $N$ & $\begin{array}{l}\text { Diarrhea } \\
\text { (recently) }\end{array}$ & $\begin{array}{c}\text { Fever } \\
\text { (Last } 2 \text { weeks) }\end{array}$ & $\begin{array}{c}\text { Cough } \\
\text { (Last } 2 \text { weeks) }\end{array}$ & $\mathrm{N}$ & $\begin{array}{l}\text { Diarrhea } \\
\text { (recently) }\end{array}$ & $\begin{array}{c}\text { Fever } \\
\text { (Last } 2 \text { weeks) }\end{array}$ & $\begin{array}{c}\text { Cough } \\
\text { (Last } 2 \text { weeks) }\end{array}$ \\
\hline & No. & $(\%)$ & $(\%)$ & $(\%)$ & No. & $(\%)$ & $(\%)$ & $(\%)$ & No. & $(\%)$ & $(\%)$ & $(\%)$ \\
\hline 00 & 184 & 6.0 & 3.3 & 4.9 & 104 & 8.7 & 2.9 & 4.8 & 80 & 2.5 & 3.8 & 5.0 \\
\hline 01 & 490 & 6.7 & 8.6 & 12.7 & 232 & 7.3 & 9.5 & 14.7 & 258 & 6.2 & 7.8 & 10.9 \\
\hline 02 & 628 & 12.3 & 9.4 & 18.2 & 307 & 12.1 & 10.1 & 18.2 & 321 & 12.5 & 8.7 & 18.1 \\
\hline 03 & 627 & 12.6 & 13.4 & 20.1 & 321 & 15.6 & 13.4 & 21.8 & 306 & 9.5 & 13.4 & 18.4 \\
\hline 04 & 691 & 14.2 & 15.6 & 22.6 & 330 & 17.9 & 17.9 & 23.9 & 361 & 10.8 & 13.6 & 21.3 \\
\hline 05 & 726 & 14.0 & 15.7 & 20.4 & 349 & 14.6 & 17.5 & 23.5 & 377 & 13.5 & 14.1 & 17.5 \\
\hline 06 & 710 & 20.0 & 19.3 & 25.4 & 365 & 20.5 & 19.7 & 26.3 & 345 & 19.4 & 18.8 & 24.3 \\
\hline 07 & 744 & 18.3 & 22.7 & 26.5 & 364 & 19.5 & 26.6 & 28.3 & 380 & 17.1 & 18.9 & 24.7 \\
\hline 08 & 760 & 17.5 & 20.5 & 23.2 & 414 & 20.3 & 24.2 & 26.1 & 346 & 14.2 & 16.2 & 19.7 \\
\hline 09 & 703 & 19.8 & 20.9 & 25.9 & 354 & 18.9 & 20.9 & 26.6 & 349 & 20.6 & 20.9 & 25.2 \\
\hline 10 & 690 & 16.7 & 22.0 & 25.4 & 347 & 17.0 & 22.5 & 23.6 & 343 & 16.3 & 21.6 & 27.2 \\
\hline 11 & 609 & 17.4 & 21.5 & 23.5 & 297 & 14.1 & 25.3 & 25.6 & 312 & 20.5 & 17.9 & 21.5 \\
\hline Total & 7562 & 15.5 & 17.3 & 22.1 & 3784 & 16.4 & 18.9 & 23.4 & 3778 & 14.6 & 15.6 & 20.7 \\
\hline
\end{tabular}

Source: NFHS-3, India.

tion of nutritional status of infants in India. It is seen that in India, 27.8\% infants are underweight, $22.5 \%$ are stunted and $26.7 \%$ are wasted though there is a great variation according to different zones and states in India. It is seen that in India lowest underweight, stunted and wasted infants are found in the north-east zone and highest percentage is found in the central zone. The state with the least percentage of underweight infants is Mizoram (7.3\%), which is followed by Sikkim (7.6\%), Manipur $(11.0 \%)$, Kerala $(11.5 \%)$ and Nagaland (13.9\%). The states with less than $15 \%$ stunted infants are Manipur $(11.9 \%)$, Kerala $(12.8 \%)$ and Goa $(14.5 \%)$. There are only two states with less than $15 \%$ wasted infants, namely Mizoram (11.0\%) and Punjab (13.1\%). High prevalent States $(>35 \%)$ are Jharkhond (39.4\%), Chhattisgarh (41.5\%), Bihar (42.6\%), and Madhya Pradesh, (45.5\%) for underweight, only Chattisgarh $(35.5 \%)$ for stunted and Jharkhond (36.7\%), Bihar (37.2\%) and Madhya Pradesh (43.6\%) for wasted.

Table 5 describes the state- and zone-wise non-immunization status of infants in India. Only $26.8 \%$ of Indian infants have not taken BCG vaccine. In case of DPT, Polio and Measles, these percentages are alarmingly very high. The non-immunized percentages of infants are $60.9 \%, 53.4 \%$ and $82.2 \%$ respectively for DPT, Polio and Measles. Thus most of the infants are not immunized. The variation in the non-immunization status over zones is not expected to be much as each zone consists of a number of states. For BCG, it ranges from $25.4 \%$ in the North Zone to $30.0 \%$ in the West Zone. Corresponding lowest and the highest percentages are 60.0\% (NorthEast Zone) and 62.0\% (East Zone) for DPT, 51.2\% (North-East Zone) and 56.0\% (East Zone) for Polio and 80.8\% (East Zone) and 83.2\% (North-East Zone) for Measles. Variation of these percentages among the states is also not much. These percentages are $21.5 \%$ (Sikkim) and 35.4\% (Arunachal Pradesh) for BCG; 55.7\% (Madhya Pradesh) and 68.0\% (New Delhi) for DPT; $44.3 \%$ (Sikkim) and 62.4\% (New Delhi) for Polio and 78.0\% (Bihar) and 86.3\% (Tripura) for Measles.

Zone- and state-wise morbidity patterns of infants are given in Table 6. Overall percentages of occurrences of diarrhea, fever and cough are $15.5 \%, 17.3 \%$ and $22.1 \%$ respectively. South Zone has the minimum occurrences for Diarrhea (11.2\%) and Cough (16.8) and North Zone has the minimum occurrences of fever $(15.1 \%)$. So far as diarrhea is concerned North Zone has the maximum occurrence (19.2\%), whereas East Zone takes the highest position in both the cases of fever and cough with $22.0 \%$ and $27.5 \%$ respectively. When seen state wise, Meghalaya can boast of having the lowest percentages of infants to be affected by each of the three types of morbidity considered here, namely Diarrhea (6.0\%), Fever $(5.2 \%)$ and Cough (7.8\%). The corresponding highest prevalent states are Gujarat $(24.2 \%)$, Tripura $(34.3 \%)$ and Tripura $(42.2 \%)$.

Table 7 shows the distribution of nutritional status, non-immunization status and morbidity pattern of infants in India among different socio-economic groups. It is seen that socio-economic groups have profound effect on 
Table 4. Zone- and state-wise percentages of underweight, stunted and wasted infants in India, 2005-2006.

\begin{tabular}{|c|c|c|c|c|}
\hline \multirow{2}{*}{ Zones and States } & \multicolumn{4}{|c|}{ Nutritional status (\%) } \\
\hline & $\mathbf{N}$ & Underweight & Stunted & Wasted \\
\hline North-East & 1394 & 18.1 & 18.4 & 20.5 \\
\hline Arunachal Pradesh & 127 & 17.3 & 16.5 & 18.9 \\
\hline Assam & 230 & 28.7 & 27.0 & 21.7 \\
\hline Manipur & 336 & 11.0 & 11.9 & 18.5 \\
\hline Meghalaya & 116 & 34.5 & 26.7 & 34.5 \\
\hline Mizoram & 109 & 7.3 & 15.6 & 11.0 \\
\hline Nagaland & 295 & 13.9 & 16.9 & 19.3 \\
\hline Sikkim & 79 & 7.6 & 16.5 & 15.2 \\
\hline Tripura & 102 & 32.4 & 22.5 & 28.4 \\
\hline East & 1296 & 35.0 & 25.9 & 30.3 \\
\hline Bihar & 401 & 42.6 & 26.9 & 37.2 \\
\hline Jharkhand & 251 & 39.4 & 23.5 & 36.7 \\
\hline Orissa & 302 & 32.1 & 26.8 & 24.8 \\
\hline West Bengal & 342 & 25.4 & 25.7 & 22.5 \\
\hline Central & 1769 & 36.6 & 25.6 & 33.6 \\
\hline Madhya Pradesh & 488 & 45.5 & 22.5 & 43.6 \\
\hline Chhattisgarh & 282 & 41.5 & 35.5 & 33.7 \\
\hline Uttar Pradesh & 999 & 30.8 & 24.3 & 28.6 \\
\hline West & 730 & 26.6 & 22.9 & 23.3 \\
\hline Goa & 117 & 22.2 & 14.5 & 24.8 \\
\hline Gujarat & 244 & 29.9 & 27.0 & 20.5 \\
\hline Maharashtra & 369 & 25.7 & 22.8 & 24.7 \\
\hline North & 1446 & 246 & 21.2 & 23.9 \\
\hline Haryana & 225 & 31.6 & 24.4 & 32.0 \\
\hline Himachal Pradesh & 151 & 26.5 & 17.9 & 25.8 \\
\hline Jammu \& Kashmir & 167 & 22.2 & 21.0 & 25.7 \\
\hline New Delhi & 125 & 20.8 & 19.2 & 27.2 \\
\hline Punjab & 221 & 19.0 & 18.1 & 13.1 \\
\hline Rajasthan & 338 & 24.9 & 19.8 & 25.1 \\
\hline Uttranchal & 219 & 25.1 & 26.5 & 20.1 \\
\hline South & 927 & 21.5 & 19.8 & 24.5 \\
\hline Andhra Pradesh & 286 & 24.1 & 20.3 & 21.3 \\
\hline Karnataka & 222 & 25.7 & 26.6 & 21.6 \\
\hline Kerala & 148 & 11.5 & 12.8 & 20.3 \\
\hline Tamil Nadu & 271 & 20.7 & 17.7 & 32.5 \\
\hline India & 7562 & 27.8 & 22.5 & 26.7 \\
\hline
\end{tabular}

Source: NFHS-3, India.

nutritional status but has negligible effect on both immunization status and morbidity of infants in India. So far as nutritional statuses are concerned, infants from richer households, from urban areas and of higher educated mothers are found to be least undernourished, stunted or wasted. Infants from Christian families are also least affected by any of the forms of malnutrition. However, the difference between male and female infants is not much.

The findings in Table 7 is confirmed in Table 8, which shows the impact of socio-economic variables on the nutritional, non-immunization and morbidity status of 
Table 5. Zone- and state-wise percentages of non-immunized infants in India, 2005-2006.

\begin{tabular}{|c|c|c|c|c|c|}
\hline \multirow{2}{*}{ Zones and States } & \multicolumn{5}{|c|}{ Non-Immunized } \\
\hline & $\mathbf{N}$ & BCG & DPT & Polio & Measles \\
\hline North-East & 1394 & 27.8 & 60.0 & 51.2 & 83.2 \\
\hline Arunachal Pradesh & 127 & 35.4 & 66.9 & 54.3 & 85.8 \\
\hline Assam & 230 & 28.3 & 58.1 & 47.4 & 80.7 \\
\hline Manipur & 336 & 27.4 & 62.5 & 51.5 & 83.0 \\
\hline Meghalaya & 116 & 30.2 & 60.9 & 51.7 & 81.7 \\
\hline Mizoram & 109 & 28.4 & 57.8 & 52.3 & 86.2 \\
\hline Nagaland & 295 & 24.7 & 56.5 & 53.6 & 83.3 \\
\hline Sikkim & 79 & 21.5 & 57.0 & 44.3 & 81.0 \\
\hline Tripura & 102 & 28.4 & 61.8 & 52.0 & 86.3 \\
\hline East & 1296 & 26.6 & 62.0 & 56.0 & 80.8 \\
\hline Bihar & 401 & 25.5 & 57.3 & 52.5 & 78.0 \\
\hline Jharkhond & 251 & 26.7 & 67.3 & 59.4 & 84.9 \\
\hline Orissa & 302 & 26.2 & 60.3 & 58.6 & 79.5 \\
\hline West Bengal & 342 & 28.1 & 65.1 & 55.3 & 82.4 \\
\hline Central & 1769 & 25.3 & 59.8 & 52.1 & 82.3 \\
\hline Madhya Pradesh & 488 & 23.4 & 55.7 & 50.2 & 81.7 \\
\hline Chhattisgarh & 282 & 21.6 & 58.5 & 50.4 & 79.7 \\
\hline Uttar Pradesh & 999 & 27.3 & 62.1 & 53.5 & 83.3 \\
\hline West & 730 & 30.0 & 61.4 & 55.2 & 81.5 \\
\hline Goa & 117 & 26.5 & 59.8 & 53.0 & 78.6 \\
\hline Gujarat & 244 & 31.1 & 61.5 & 55.7 & 82.8 \\
\hline Maharashtra & 369 & 30.4 & 61.8 & 55.6 & 81.6 \\
\hline North & 1446 & 25.4 & 61.9 & 54.4 & 82.3 \\
\hline Haryana & 225 & 23.6 & 58.2 & 53.8 & 84.3 \\
\hline Himachal Pradesh & 151 & 29.1 & 66.2 & 56.3 & 86.1 \\
\hline Jammu \& Kashmir & 167 & 28.1 & 62.9 & 56.9 & 82.0 \\
\hline New Delhi & 125 & 23.2 & 68.0 & 62.4 & 82.4 \\
\hline Punjab & 221 & 26.7 & 64.7 & 58.4 & 84.2 \\
\hline Rajasthan & 338 & 23.4 & 58.2 & 49.7 & 80.7 \\
\hline Uttranchal & 219 & 25.6 & 61.2 & 50.7 & 78.5 \\
\hline South & 927 & 28.6 & 61.3 & 52.3 & 83.0 \\
\hline Andhra Pradesh & 286 & 30.1 & 58.2 & 48.3 & 80.6 \\
\hline Karnataka & 222 & 30.6 & 60.8 & 49.3 & 83.3 \\
\hline Kerala & 148 & 24.3 & 60.1 & 58.1 & 83.1 \\
\hline Tamil Nadu & 271 & 27.7 & 65.7 & 55.7 & 85.1 \\
\hline India & 7562 & 26.8 & 60.9 & 53.4 & 82.2 \\
\hline
\end{tabular}

Source: NFHS-3, India.

the infants of India through categorical logistic regression. When immunization status is regressed on the socio-economic categorical variables, none of the coefficients is found to be statistically insignificant. This result only shows that the responses to the immunization drives are uniform over all the socio-economic groups. For morbidity status the effective variables are gender on fever, religion on Cough and literacy on all the three types of morbidity. Wealth index do not have any significant effect on any of the types of morbidity. On the other hand the socio-economic variables, namely religion, literacy status of mother and wealth index of the house- 
Table 6. Morbidity statuses of infants in different zones and states in India.

\begin{tabular}{|c|c|c|c|c|}
\hline \multirow{2}{*}{ Zones and States } & \multicolumn{4}{|c|}{ Morbidity } \\
\hline & $\mathbf{N}$ & Diarrhea & Fever & Cough \\
\hline North-East & 1394 & 12.1 & 17.0 & 20.8 \\
\hline Arunachal Pradesh & 127 & 17.3 & 22.8 & 26.8 \\
\hline Assam & 230 & 10.9 & 17.4 & 20.0 \\
\hline Manipur & 336 & 11.9 & 14.3 & 22.1 \\
\hline Meghalaya & 116 & 6.0 & 5.2 & 7.8 \\
\hline Mizoram & 109 & 16.5 & 20.2 & 21.1 \\
\hline Nagaland & 295 & 10.2 & 14.6 & 14.9 \\
\hline Sikkim & 79 & 19.0 & 17.7 & 21.5 \\
\hline Tripura & 102 & 11.8 & 34.3 & 42.2 \\
\hline East & 1296 & 15.7 & 22.0 & 27.5 \\
\hline Bihar & 401 & 15.0 & 21.4 & 21.4 \\
\hline Jharkhond & 251 & 23.9 & 24.3 & 26.7 \\
\hline Orissa & 302 & 17.2 & 17.5 & 22.8 \\
\hline West Bengal & 342 & 9.1 & 24.9 & 39.2 \\
\hline Central & 1769 & 16.2 & 16.9 & 24.7 \\
\hline Madhya Pradesh & 488 & 23.6 & 15.4 & 21.3 \\
\hline Chhattisgarh & 282 & 10.3 & 12.4 & 27.3 \\
\hline Uttar Pradesh & 999 & 14.3 & 18.8 & 25.7 \\
\hline West & 730 & 17.8 & 16.4 & 22.7 \\
\hline Goa & 117 & 12.0 & 17.9 & 21.4 \\
\hline Gujarat & 244 & 24.2 & 17.2 & 29.9 \\
\hline Maharashtra & 369 & 15.4 & 15.4 & 18.4 \\
\hline North & 1446 & 19.2 & 15.1 & 18.2 \\
\hline Haryana & 225 & 22.2 & 9.8 & 12.0 \\
\hline Himachal Pradesh & 151 & 16.6 & 11.3 & 11.3 \\
\hline Jammu \& Kashmir & 167 & 22.2 & 24.6 & 18.6 \\
\hline New Delhi & 125 & 13.6 & 8.8 & 16.8 \\
\hline Punjab & 221 & 15.4 & 16.7 & 23.1 \\
\hline Rajasthan & 338 & 20.7 & 13.9 & 23.4 \\
\hline Uttranchal & 219 & 20.5 & 19.6 & 16.9 \\
\hline South & 927 & 11.2 & 15.9 & 16.8 \\
\hline Andhra Pradesh & 286 & 9.8 & 8.7 & 14.3 \\
\hline Karnataka & 222 & 15.3 & 21.2 & 20.7 \\
\hline Kerala & 148 & 11.5 & 25.0 & 19.6 \\
\hline Tamil Nadu & 271 & 9.2 & 14.0 & 14.8 \\
\hline India & 7562 & 15.5 & 17.3 & 22.1 \\
\hline
\end{tabular}

Source: NFHS-3, India.

hold, have highly significant effect on all the nutritional statuses of infants. The place of residence, sex of the infant and ethnicity do not have any significant effect on morbidity. Religions have much effect on the nutritional status, especially the Christians and communities other than Hindus and Muslims contribute to much lesser percentages underweight, stunted and wasted infants compared to Hindus and Muslims. Influence on the nutritional status was found to be the highest particularly for the highest categories of the wealth and literacy status. 
Table 7. Relationship between socio-economic variables with the nutrition, immunization and morbidity statuses of infants in India.

\begin{tabular}{|c|c|c|c|c|c|c|c|c|c|c|}
\hline \multirow{2}{*}{$\begin{array}{c}\text { Variables } \\
\text { Type of place } \\
\end{array}$} & \multicolumn{3}{|c|}{ Nutritional status } & \multicolumn{4}{|c|}{ Immunization (not taken) status } & \multicolumn{3}{|c|}{ Morbidity } \\
\hline & Underweight & Stunted & Wasted & BCG & DPT & Polio & Measles & Diarrhea & Fever & Cough \\
\hline Rural & 31.3 & 24.8 & 27.9 & 26.9 & 60.7 & 54.2 & 82.2 & 15.6 & 17.1 & 21.7 \\
\hline Urban & 21.2 & 18.2 & 24.3 & 26.7 & 61.5 & 53.4 & 82.3 & 15.2 & 17.5 & 22.7 \\
\hline \multicolumn{11}{|l|}{ Sex of the child } \\
\hline Male & 28.0 & 23.5 & 26.5 & 26.6 & 60.5 & 52.5 & 81.9 & 16.4 & 18.9 & 23.4 \\
\hline Female & 27.6 & 21.5 & 26.9 & 27.1 & 61.4 & 52.5 & 82.5 & 14.6 & 15.6 & 20.7 \\
\hline \multicolumn{11}{|l|}{ Ethnicity } \\
\hline $\mathrm{ST}, \mathrm{SC} \& \mathrm{OBC}$ & 30.4 & 23.9 & 28.2 & 26.0 & 60.3 & 53.4 & 82.1 & 15.6 & 16.9 & 21.8 \\
\hline General & 22.2 & 19.0 & 23.7 & 28.4 & 62.4 & 53.3 & 82.3 & 15.2 & 17.4 & 21.9 \\
\hline \multicolumn{11}{|l|}{ Religion } \\
\hline Hindu \& Muslim & 29.6 & 23.3 & 28.0 & 26.7 & 61.0 & 53.2 & 82.1 & 15.8 & 17.6 & 22.7 \\
\hline Christian \& Others & 17.0 & 18.0 & 18.3 & 27.9 & 60.5 & 54.6 & 83.2 & 13.5 & 15.0 & 18.5 \\
\hline \multicolumn{11}{|l|}{ Mother's Education } \\
\hline Illiterate \& Primary & 24.0 & 19.8 & 24.1 & 27.4 & 60.9 & 54.0 & 82.0 & 16.6 & 18.7 & 23.7 \\
\hline Sec. \& Higher & 11.4 & 11.4 & 18.2 & 24.8 & 61.8 & 50.8 & 81.2 & 13.6 & 11.1 & 15.8 \\
\hline \multicolumn{11}{|l|}{ Wealth Index } \\
\hline Poorest \& Poorer & 39.4 & 28.8 & 32.6 & 27.0 & 60.8 & 53.7 & 82.2 & 14.1 & 16.9 & 23.0 \\
\hline Middle & 28.2 & 24.0 & 26.8 & 26.9 & 61.1 & 53.2 & 83.0 & 16.2 & 17.9 & 21.5 \\
\hline Richer \& Richest & 17.8 & 16.5 & 21.6 & 26.7 & 61.0 & 53.2 & 81.9 & 16.3 & 17.2 & 21.5 \\
\hline
\end{tabular}

Source: NFHS-3, India.

Table 8. Categorical logistic regression nutrition, immunization and morbidity statuses of infants on the socio-economic variables in India.

\begin{tabular}{|c|c|c|c|c|c|c|c|c|c|c|}
\hline \multirow{2}{*}{$\begin{array}{c}\text { Variables } \\
\text { Type of place }\end{array}$} & \multicolumn{3}{|c|}{ Nutritional status } & \multicolumn{4}{|c|}{ Immunization (not taken ) status } & \multicolumn{3}{|c|}{ Morbidity } \\
\hline & Underweight & Stunted & Wasted & BCG & DPT & Polio & Measles & Diarrhea & Fever & Cough \\
\hline Rural & 1.00 & 1.00 & 1.00 & 1.00 & 1.00 & 1.00 & 1.00 & 1.00 & 1.00 & 1.00 \\
\hline Urban & 0.897 & 0.940 & 1.110 & 1.062 & 1.014 & 1.019 & 0.967 & 0.813 & 1.024 & 1.095 \\
\hline \multicolumn{11}{|l|}{ Sex of the child } \\
\hline Female & 1.00 & 1.00 & 1.00 & 1.00 & 1.00 & 1.00 & 1.00 & 1.00 & 1.00 & 1.00 \\
\hline Male & 1.176 & 1.075 & 1.078 & 1.042 & 1.013 & 0.934 & 1.020 & 1.129 & $1.329^{* *}$ & 1.120 \\
\hline \multicolumn{11}{|l|}{ Ethnicity } \\
\hline $\mathrm{ST}, \mathrm{SC} \& \mathrm{OBC}$ & 1.00 & 1.00 & 1.00 & 1.00 & 1.00 & 1.00 & 1.00 & 1.00 & 1.00 & 1.00 \\
\hline General & 0.887 & 0.953 & 0.892 & 1.195 & 1.179 & 1.044 & 1.024 & 0.915 & 0.948 & 0.928 \\
\hline \multicolumn{11}{|l|}{ Religion } \\
\hline Christian \& Others & $0.480^{* *}$ & $0.742^{* *}$ & $0.524^{* *}$ & 1.074 & 0.951 & 1.000 & 1.004 & 0.843 & 0.939 & $0.746^{* *}$ \\
\hline \multicolumn{11}{|l|}{ Mother's education } \\
\hline Illiterate \& Primary & 1.00 & 1.00 & 1.00 & 1.00 & 1.00 & 1.00 & 1.00 & 1.00 & 1.00 & 1.00 \\
\hline Sec. \& Higher & $0.563^{* *}$ & $0.648^{* *}$ & $0.779^{*}$ & 0.843 & 1.021 & 0.856 & 0.890 & $0.742^{*}$ & $0.555^{* *}$ & $0.639^{* *}$ \\
\hline \multicolumn{11}{|l|}{ Wealth Index } \\
\hline Poorest \& Poorer & 1.00 & 1.00 & 1.00 & 1.00 & 1.00 & 1.00 & 1.00 & 1.00 & 1.00 & 1.00 \\
\hline Middle & $0.697^{* *}$ & 0.851 & 0.868 & 1.012 & 1.082 & 0.987 & 1.124 & 1.035 & 0.899 & 0.878 \\
\hline Richer \& Richest & $0.437^{* *}$ & $0.554^{* *}$ & $0.688^{* *}$ & 1.010 & 1.049 & 1.064 & 1.258 & 1.352 & 0.956 & 0.871 \\
\hline
\end{tabular}

Source: NFHS-3, India. 


\section{DISCUSSIONS}

From the above results, it is seen that percentages of malnourished infants range from 22 to 28 percent when the three types, namely underweight, stunted and wasted infants are considered. In respect of immunization status, where India's moto was all children and pregnant mothers to be immunized by 1990 [12], only $73.2 \%$ were immunized by BCG, $17.9 \%$ are from measles, $39.1 \%$ from DPT (triple dose) and 46.7\% from Polio during 2005-2006. A significant portion (15 to 22 percent) of infants is suffering from diarrhea, fever and cough, though there are considerable variations over states and zones. North-East zone is seen to be in a better condition so far as nutritional and immunization statuses are concerned. It is also interesting to note that even in New Delhi, percentage of non-immunization infants is very high, but the reason is not clear. High occurrences of malnourished infants are seen in most states of east and north zone. This may be because, according to World Bank [13], 421 million poor people are concentrated in the eight Northand East-Indian states. These states are Bihar, Chattisgarh, Jharkhond, MP, Orissa, Rajasthan, UP and West Bengal.

It is also clear from our analysis that mother's education and wealth index have profound effects on nutriational status and also on morbidity but there is no impact of socio-economic variables on immunization because immunization is very much dependent on the infrastructure of state health. Also the responses to immunization drives seem to be uniform over all socio-economic groups. Low immunization status in the east and the central zones is corroborated with the World Bank report that the coverage of ICDS developmental programme for children in Bihar, Rajasthan, UP, Orissa and Madhya Pradesh is very low and it ranks in the bottom ten [11].

Though mother's education and income may be adjudged as the most effective factor to reduce malnutrition, but health infrastructures of the states may also be responsible for bringing good health among children. The health infrastructures are not considered in the present analysis.

To conclude, the results found in this paper give clear cut indications for the government and NGOs to take actions to ameliorate poverty and to improve the level of education, especially of female population in India.

\section{REFERENCES}

[1] Chen, L.C., Chowdhury, A.K.M.A. and Huffman, S.L. (1980) Anthropometric assessment of energy-protein mal- nutrition and subsequent risk of mortality among preschool aged children. American Journal of Clinical Nutrition, 33, 1836-1845.

[2] Ruzicka, L.T. and Kane, P. (1985) Nutrition and child survival in south Asia. In: Srinivasan, K. and Mukerji, S., Eds., Dynamics of Population and Family Welfare, Himalaya Publishing House, Bombay, 333-357.

[3] Santhanakrishnan, B.R. and Ramalingam, R. (1987) Risk factors of mortality in children with diarrhoeal disease in Madras, India. Journal of Diarrhoeal Disease Research, 5, 36-39.

[4] Singh, K.P. (1989) Green revolution and child survival in the state of Punjab. International.

[5] Sommer, A. and Loewenstein, M.S. (1975) Nutritional status and mortality: A prospective validation of the QUAC stick. American Journal of Clinical Nutrition, 28, 287292.

[6] Vella, V., Tomkins, A., Borghesi, A., Migliori, G.B., Adriko, B.C. and Crevatin, E. (1992) Determinants of child nutrition and mortality in north-west Uganda. Bulletin of the World Health Organization, 70, 637-643.

[7] Brown, K.E., Black, R.E. and Becker, S. (1982) Seasonal changes in nutritional status and the prevalence of malnutrition in a longitudinal study of young children in rural Bangladesh. American Journal of Clinical Nutrition, 36, 303-313.

[8] Sommerfelt, A.E. and Stewart, M.K. (1994) Children's nutritional status. DHS Comparative Studies, No. 12. Macro International, Demographic and Health Surveys, Calverton.

[9] International Institute for Population Sciences (IIPS) and ORC Macro (2007) National family health survey (NFHS3), 2005-2006, Vol. 1. IIPS, Mumbai.

[10] World Health Organization (1995) Physical status: The use and interpretation of anthropometry. WHO Technical Report Series No. 854. WHO, Geneva.

[11] Rutstein, S. (1999) Wealth versus expenditure: Comparison between the DHS wealth index and household expenditures in your departments of Guatemala. ORC Macro, Calverton.

[12] Banerjee, D. (1986) Technocratic approach to health: Western response to Alma Ata. Economic and Political Weekly, 21, 1233-1234.

[13] World Bank Organization (2006) News and broadcasturgent action needed to overcome persistent malnutrition in India, say World Bank Report's web. www.worldbank.org 